\title{
EFEKTIFITAS PENGGUNAAN MEDIA KOMUNIKASI DALAM RANGKA SOSIALISASI PROGRAM GPMB (GERAKAN PEMBINAAN MASYARAKAT BACA) DI JAWA BARAT
}

\author{
Tine Silvana $\mathbf{R}^{1)}$, H. Rohanda ${ }^{2)}$ \\ ${ }^{1)}$ Dosen Prodi Ilmu Komunikasi, Universitas Padjajaran, \\ ${ }^{2)}$ Dosen Prodi Ilmu Komunikasi, Universitas Padjajaran \\ Email:tine.silvana@gmail.com
}

\begin{abstract}
This research explore efectivity of media uses for GPMB's (Gerakan Pembinaan Masyarakat Baca) program at jawa Barat. This research aim to explore attractiveness of message, content of information, and obstacles of media communication at socialization of GPMB's program in Jawa Barat. The research method's is qualitative descriptivvw which explain the fact sistematicly ang has specific population characteristics carefully. The data collected by interview 8 leader of library as coach of GPMB, observation to road show at Ciamis, Bogor and Karawang. The result of this research show content of information use manual book, brochure, news paper and billboard was completed about this program. The format of content of information was easy to understanded. The obstacles from delivery message was lack of interested for read. The efective way to delivery the message was from roadshow but they cann't delivery all of content information to all of target information. This research suggest "Bapusipda" will guide and give media information routinely to all library at Jawa Barat
\end{abstract}

Keywords: Efectivity of media communication, socialization, Gerakan Pembinaan Masyarakat Baca

\section{PENDAHULUAN}

Unesco mencatat tentang indeks baca masyarakat dunia yaitu Amerika Serikat 53\%, jepang 38\% Malaysia $15 \%$ dan Indonesia 0,9 \% ( Berita Buku no 67,th V111 February 1997). Indeks terebut memperlihatkan bahwa masyarakat Indonesia masih sangat rendah kebiasaan membacanya dibandingkan dengan masyarakat dunia lainnya. Dari hasil pemetaan tentang budaya baca masyarakat Provinsi Jawa Barat melalui pemanfaatan perpustakaan desa/ kelurahan terlihat bahwa ; Frekuensi menonton TV 1-3 jam, ngobrol 1-2 jam per hari, sedangkan membaca kurang dari 1 jam per hari ( BAPUSIPDA :2010) Kemudian media yang mereka gunakan adalah TV lebih dari 40 $\%$, radio lebih dari $50 \%$ dan surat kabar $20 \%$ dan buku kurang dari $10 \%$. Hal ini pun ditandai dengan kepemilikan buku 1:20 orang. ( Bapusipda Jabar, 2009).

Kepemilikan buku di keluarga berkisar 5- 50 judul, dengan anggaran belanja buku per keluarga (RP.20.000 per bulan) untuk masyarakat kota , ( Rp.10.000 perbulan ) untuk masyarakat pedesaan. Mereka menggunakan surat khabar dan majalah dengan meminjam atau membaca di perpustakaan.

Motivasi penggunaan media seperti buku, surat kabar, majalah, serta nonton TV 


\section{Vol. 2 No.1 Agustus 2017}

merupakan salah satu pengisi waktu senggang saja. Hal inipun terlihat dari tema-tema bacaan dan tontonan ( TV dan film) seperti horror, petualangan, aksi, misteri, dan tema tema hiburan lainnya seperti komedi ( Rohanda, 2010). Sehingga fungsi media sebagai edukasi, informasi, membangun identitas dan kepribadian, integrasi dan interaksi social serta kesadaran untuk pengembangan wawasan dan hiburan. Media mempunyai peran yang sangat besar dalam kehidupan social masyarakat, sehingga kehadirannya dapat difungsikan untuk menyampaikan pesan dan program-program pemerintah.

Kondisi masyarakat jawa barat seperti dianggapkan oleh ketua pengurus Gerakan Pemasyarakatan Minat Baca (GPMB) Provinsi Jawa barat $\mathrm{Bu}$ Om Nurohmah mengatakan bahwa minat baca masyarakat Jawa Barat masih dapat dikatakan kondisi rendah, hal ini ditandai dengan masih rendahnya penggunaan perpustakaan, yaitu frekuensi kunjungan ke perpustakaan hanya satu kali dalam sebulan, dan jumlah pinjaman buku dua judul perminggu, dan untuk daerah tertentu masih ada yang buta huruf terutama usia 46 tahun ke atas. Juga masih ada drop out di tingkat SD (wawancara tgl 27 Juli 2011) di Bapusipda Jawa Barat. Selanjutnya beliau mengatakan pula bahwa Pembinaan masyarakat baca Jawa Barat tidak terkoordinasikan dengan baik ,dilakukan oleh masing-masing instansi dan organisasi social. Sehingga perlu ada wadah yang professional, sesuai dengan undangundang no 43 tahun 2007 tentang perpustakaan pasal 48 ayat (1) Pembudayaan kegemaran membaca dilakukan melalui keluarga, satuan pendidikan, dan masyarakat. Kemudian pada pasal 49 pemerintah daerah dan masyarakat mendorong tumbuhnya taman pustaka dan rumah baca untuk menunjang pembudayaan gemar membaca. Selanjutnya pasal 50 menyatakan pemerintah, pemerintah daerah memfasilitasi dan mendorong pembudayaan (Undang-undang perpustakaan RI no 23 tahun 2007).

Berdasarkan Undang-undang dan kondisi factual yang ada maka dibentuk Gerakan Pembinaan Minat Baca (GPMB) provinsi Jawa Barat, dengan berbagai programnya, programprogram tersebut disosialisasikan lewat media komunikasi seperti TV, Radio, surat kabar, buku panduan, dan selebaran-selebaran tentunya tidak sedikit biaya dan tenaga yang dikeluarkan untuk memanfaatkan media (TV, Radio, Internet, surat kabar) buku panduan dan selebaran, apakah media tersebut sudah berfungsi secara efektif ?

Hal ini perlu dikaji lebih jauh tentang kemanfaatan dan keefektivitasan media itu, atau sudahkah media tadi dimanfaatkan secara optimal oleh GPMB dalam mensosialisasikan program-program yang sudah di rancang oleh GPMB tersebut. 


\section{PERMASALAHAN}

Berdasarkan latar belakang dan pendahuluan di atas maka dapat dirumuskan masalahnya sebagai berikut :

Sejauhmana efektifitas media Komunikasi dalam acara Road Show Pada Program sosialisasi Gerakan Pemasyarakatan Minat Baca (GPMB) yang di lakukan oleh Bapusipda Provinsi Jawa Barat dalam menumbuhkan Budaya baca.

Sedangkan fokus penelitian adalah :

1) Bagaimana daya tarik penyajian media komunikasi cetak dalam bentuk buku panduan, brosur, surat kabar,dan billboard dalam menumbuhkan budaya baca?

2) Bagaimana isi informasi media komunikasin cetak dalam bentuk buku panduan, brosur,surat kabar, billbord dalam menumbuhkan budaya baca ?

3) Bagaimana kendala yang ditemukan dalam penyebaran informasi melalui media komunikasi dalam bentuk buku panduan, surat kabar, billboard untuk menumbuhkan budaya baca?

\section{PEMBAHASAN}

Perubahan paradigma dunia penerbitan saat ini, dimana awal mulanya industri penerbitan dari industri rumahan ( home industri ) menjadi industri besar. Pada saat ini disebut era komunikasi cetak ( printing Era of communication), Media cetak membanjiri masyarakat sementara budaya baca masyarakat masih rendah.

Ada beberapa proses penilaian atau indeks baca yaitu :

- Mampu membaca

- Tersedia Media baca

- Kemudahan memperoleh bacaan

- Motivasi membaca

- Mencintai bacaan

- Kebiasaan Membaca

- Kebutuhan Membaca

- Budaya baca (Rohanda, 2009)

\subsection{Proses komunikasi}

Komunikasi merupakan sebuah transmisi pesan baik itu pesan informatif, persuasive atau koesif. Seperti sudah disinggung diatas komunikasi dapat dianggap sebagai transmisi informasi. Informasi merupakan suatu bentuk dan pola. Jadi, dengan demikian bahwa pengiriman dan penerimaan bentuk dalam komunikasi.

Proses komunikasi

a. Sumber (source) pesan yang menentukan tujuan komunikasi dan menetapkan sarana komunikasi. Sumber adalah seseorang ,kelompok/organisasi yang memiliki tujuan dan diupayakan untuk dibagi (share), dengan penerima/audiens. Contoh : sebuah sumber dapat berupa sebuah organisasi yang ingin mengirimkan pesan kepada ribuan konsumen dengan bantuan sebuah iklan 


\section{Vol. 2 No.1 Agustus 2017}

b. Agar dapat mentransmisi arti, maka sebuah sumber harus mengkonstruksi arti tersebut dalam bentuk tanda yang dapat mewakili ide. Hal itu dikenal dengan proses encoding. Proses encoding adalah penyandian tujuan diatas menjadi sebuah pesan. Pesan yang disampaikan dalam komunikasi pemasaran sifatnya persuasive, yaitu bagaimana membujuk konsumen agar mau melakukan pembelian.

c. Diantara sumber dan tujuan diatas terdapat satu pengait yang menghubungkan yang dinamakan saluran komunikasi (The communication chanel). Pengiriman (transmission)

Dalam proses promosi melalui media majalah ataupun tabloid, terlibat didalam aktifitas komunikasi. Variabel-variabel komunikasi yang terlibat dalam hal ini adalah variabel komunikator, variabel pesan dan media. Berdasarkan keterlibatan partisipan komunikasi dapat dijabarkan bahwa yang menjadi komunikator/sumber informasi adalah Tabloid SundaUrang dengan media komunikasinya berupa tabloid. Pembaca akan merespon suatu pesan dan memahaminya apabila mempercayai sumbernya dan menyinggung eksistensinya. Selain faktor komunikator, respon (efek) pembaca terhadap informasi dipengaruhi isi pesan itu sendiri. Respon yang muncul dapat berupa negatif/positif tergantung isi pesan yang diterima komunikannya (dalam hal ini pembaca Tabloid SundaUrang). Respon seseorang terhadap suatu pesan dipengaruhi oleh beberapa hal diantaranya adalah presepsi pribadi dan sensasi.

Sensasi adalah pengalaman elementer yang segera, yang tidak menggunakan penguraian verbal. Simbolis dan konseptual, dan terutama sekali berhubungan dengan kegiatan indera (Wolman,1973 :347 dalam Rakhamat,2001:49). Lingkungan menstimuli alat-alat inderawi manusia. Fungsi inderawi menerima informasi dari lingkungan sangat penting. Melalui alat indera manusia dapat memahami kualitas fisik lingkungannya. Lebih dari itu, indera manusia dapat memperoleh pengetahuan dan semua kemampuan untuk berinteraksi dengan lingkungan dunianya. Sedangkan presepsi ialah memberikan makna pada stimuli inderawi (sensor stimuli) (Rakhmat,2001 :51). Sensasi adalah sebagian presepsi.

Proses transmisi informasi sangat berperan dalam menyebarluaskan baik itu hanya bersifat menginformasikan, memberikan hiburan, mempengaruhi/merangsang konsumen untuk menerima atau engadopsi produk/jasa yang ditawarkan dan sebagainya.

Sejumlah faktor lain yang turut berpengaruh pada efektivitas komunikasi (Uslaksana,2003:40) :

1. semakin besar pengaruh sumber komunikasi pada penerima, semakin besar 


\section{Vol. 2 No.1 Agustus 2017}

pula dampak dan perubahan si peneriama sesuai yang dikehendaki sumber pesan..

2. komunikasi berdampak lebih kuat bila pesannya cocok denagn opini, keyankinan dan disposisi penerima.

3. Konteks sosial,grup atau gruo akan menjadi perantara komunikasi tersebut dapat diterima atau tidak.

Dalam prosesnya, komunikasi memerlukan suatu media penghubung seperti yang terlihat pada gambar 2.2, agar komunikator dapat menyampaikan pesan kepada komunikannya. Agar komunikan dapat efektif perlu diambil langkah-langkah pengembangan komunikasi agar diterima pesan yang ingin disampaikan.

\subsection{Teori Informasi Shannon \& Weaver}

Teori Informasi adalah teori yang berfokus pada sinyal-sinyal yang dikirim dari pengirim ke penerima. Untuk memahami konsep informasi, terlebih dahulu harus mengetahui konsep entropy, yaitu keserampangan, atau kurang penyusunan dalam suatu situasi. Entropy ada dalam situasi yang menyebabkan beberapa ketidak tentuan. Pendek kata, makin entropy maka makin berkurang susunan dan kemampuan diprediksi. Makin besar ketidaktentuan, makin banyak informasi. Bila suatu situasi dapat diperkirakan seluruhnya, tidak ada informasi yang tersaji. Inilah suatu kondisi yang dikenal dengan negentropy.
Informasi dapat dipikirkan sebagai sejumlah pilihan-pilihan, atau alternatifalternatif, yang bisa didapatkan pada seseorang dalam memperkirakan hasil dari suatu situasi. Dalam situasi yang kompleks dimana banyak kemungkinan hasilnya, lebih banyak informasi bisa didapatkan dibanding dalam suatu situasi yang simpel dengan sedikit hasil. Dengan kata lain, seseorang akan membutuhkan lebih banyak fakta untuk memperkirakan hasil dari suatu situasi yang kompleks dibanding memperkirakan hasil dari situasi yang simpel. Karena informasi adalah suatu fungsi dari sejumlah alternatif-alternatif, ia merefleksikan derajat kebebasan dalam membuat pilihanpilihan pada suatu situasi. Makin banyak informasi pada suatu situasi, makin banyak pilihan-pilihan yang dapat dibuat di dalam situasi itu.

Sisi putaran informasi adalah redundansi, atau kemampuan untuk dapat memperkirakan. Redundansi adalah fungsi entropy relatif, atau proporsi entropy yang ada dibanding dengan jumlah kemungkinan maksimum. Entropy adalah maksimum bila seluruh alternatif adalah sama-sama mungkin.

Teori informasi tidak berurusan dengan arti pesan-pesan, namun hanya berurusan dengan transmisi dan penerimaan pesan, terutama dalam komunikasi elektronik. Model transmisi informasi dasar dikembangkan oleh Shannon dan Weaver seperti diperlihatkan oleh gambar berikut ini: 
Sinyal Sinyal yang diterima

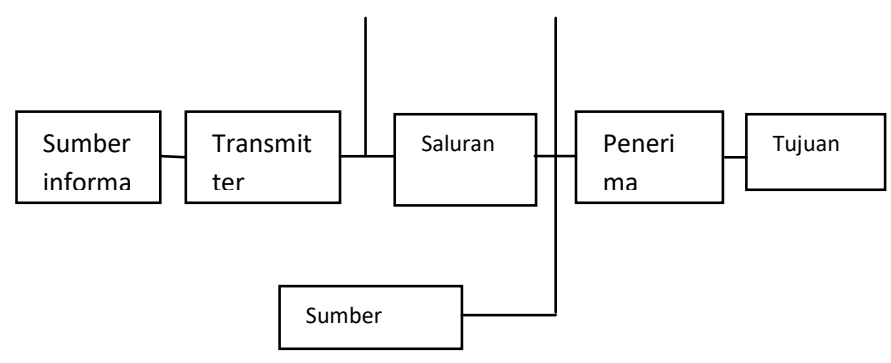

Gambar 2.1 Model Komunikasi Shannon \& Weaver (Littlejohn, 1999: 86)

Pada model ini sumber memformulasikan atau menyeleksi suatu pesan yang terdiri dari tanda-tanda yang akan ditransmit. Transmitter mengkonversi pesan itu ke dalam suatu perangkat sinyal-sinyal yang dikirim melalui saluran ke suatu penerima. Penerima itu mengkonversikan sinyal-sinyal tersebut ke dalam suatu pesan. Model ini dapat diterapkan pada berbagai situasi. Elemen akhir pada model ini, yaitu noise, adalah setiap gangguan dalam saluran yang mendistorsi atau menutupi sinyal itu. Baik pesan itu dikodekan ke dalam bahasa biasa, sinyal-sinyal elektronik, ataupun kode verbal atau non verbal lain, masalah transmisi adalah sama, yaitu merekonstruksi pesan secara akurat pada tujuan.

Setelah terjadinya noise maka peran redundansi pun mulai dapat terlihat. Redundansi mengkompensasi noise. Saat noise mendistorsi, menutupi, atau mengganti sinyalsinyal, redundansi memperbolehkan penerima untuk mengoreksi atau mengisi data yang hilang atau terdistorsi.

Faktor lain yang membatasi akurasi transmisi adalah kapasitas saluran. Kapasitas saluran biasanya didefinisikan dengan jumlah informasi maksimum yang dapat ditransmisikan pada satu saluran dalam perioda waktu yang diberikan, misalnya per detik. Jumlah informasi aktual dalam saluran disebut throughput. Jika throughput melebihi kapasitas saluran, distorsi akan muncul.

Untuk mendapatkan transmisi yang efisien diperlukan pengkodean pada suatu kecepatan maksimum yang tidak akan melebihi kapasitas saluran. Itu juga berarti menggunakan suatu kode dengan redundansi cukup untuk mengkompensasi sejumlah noise yang timbul di saluran. Jika ada terlalu banyak redundansi, transmisi akan menjadi tidak efisien, namun jika terlalu sedikit maka transmisi menjadi tidak akurat.

\subsection{Peranan Komunikasi Dalam Sosialisasi}

Sosialisasi dalam pengertian luas dimaksudkan sebagai proses penyebaran informasi atau konsep baru kepada masyarakat sehingga masyarakat mengetahuinya dan memahami terhadap informasi atau konsep baru tersebut, Wright menyatakan bahwa sosialisasi tidak pernah "total" dan merupakan proses yang terus berlangsung --- bergerak sejak masa kanak-kanak sampai tua (Wright, 1985:182) 


\section{Vol. 2 No.1 Agustus 2017}

Wright, lebih lanjut menyatakan bahwa : "Sejumlah besar sosialisasi dilakukan dengan sengaja. Tetapi sosialisasi juga terjadi secara tidak disadari ketika individu mengambil petunjuk mengenai norma-norma sosial tanpa pengajaran khusus mengenai hal tersebut." (Wright, 1985:183)

Proses sosialisasi ini terjadi melalui interaksi sosial, yaitu hubungan antar manusia yang menghasilkan suatu proses pengaruhmempengaruhi (Susanto, 1999:13). Suatu interaksi sosial tidak akan mungkin terjadi apabila tidak memenuhi dua syarat, yaitu: (1) kontak sosial; (2) komunikasi. Oleh karenanya, di dalam proses sosialisasi selalu terjadi proses komunikasi (Soekanto, 1999:71).

Komunikasi yang berkaitan dengan proses sosialisasi adalah komunikasi sosial. Menurut Astrid S. Susanto (1992), komunikasi sosial adalah salah satu bentuk komunikasi yang lebih intensif, dimana komunikasi terjadi secara langsung antara komunikator dan komunikan, sehingga situasi komunikasi berlangsung dua arah dan lebih diarahkan kepada pencapaian suatu situasi integrasi sosial, melalui kegiatan ini terjadilah aktualisasi dari berbagai masalah yang dibahas (Bungin, 2006:32).

Komunikasi sosial sekaligus suatu proses sosialisasi dan untuk pencapaian stabilitas sosial, tata tertib sosial, penerusan nilai-nilai lama dan baru yang diagungkan oleh suatu masyarakat dipupuk, dibina dan diperluas. Melalui komunikasi sosial, masalahmasalah sosial dipecahkan melalui konsensus (Bungin, 2006:32).

Tak jarang pula, sosialisasi dilakukan untuk memperkenalkan gagasan-gagasan kepada masyarakat dengan asumsi bahwa masyarakat tersebut tidak mengetahui gagasan tersebut secara pasti.

Kebauran suatu ide atau gagasan tidaklah selamanya benar-benar baru, melainkan hanya karena dianggap baru oleh penerima (Arifin, 1994:21). Dalam proses komunikasi seperti inilah yang biasa disebut komunikasi pembaharuan (inovasi) sangat memerlukan perencanaan dan perumusan strategi (Arifin, 1994:10-11).

\subsection{Jenis Media Komunikasi}

\section{1) Buku}

Buku mempunyai peran yang cukup penting dalam menyampaikan pesan pesan budaya atau informasi untuk berbagai kepentingan, seperti pendidikan,hiburan, dan program kerja. Karena buku mempunyai beberapa kepentingan dibandingkan dengan media komunikasi lainnya, tentu nya kelemahannyapun ada, misalnya informasinya sudah out of date atau usang, dibandingkan dengan dengan majalah, surat kabar, TV, Radio, internet, demikian pula jika dibandingkan dengan selebaran.

Di Indonesia sendiri buku memiliki peran yang sangat sentral, terutama di bidang 


\section{Vol. 2 No.1 Agustus 2017}

pendidikan. Hampir setiap harinya seluruh pelajar dan pengajar di Indonesia menggunakan Buku pelajaran/Buku teks (textbook) sebagai media belajar yang sentral. Walaupun kini banyak ditemukan metode belajar baru seperti e-Learning yang memanfaatkan teknologi internet sebagai media belajar namun metode itu belum mampu menggeser penggunaan buku teks sebagai media belajar yang dominan di indonesia. Dalam metode belajar e-Learning teknologi internet digunakan untuk mengakses materi belajar, dalam hal ini internet tidak hanya digunakan untuk mengakses materi belajar tetapi juga digunakan untuk berinteraksi dan berkomunikasi dengan pengajar dan sesama siswa sehingga mendapat dukungan dalam proses belajar. Namun, sayangnya metode tersebut hanya mampu menjadi sarana pelengkap saja dan belum mampu menggeser peran buku teks sebagai media belajar yang sentral. Karena perannya yang begitu sentral dalam dunia pendidikan maka bisa dikatakan kualitas anak didik di indonesia dapat dilacak melalui tinggi rendahnya mutu buku teks di Indonesia.

\section{2) Surat kabar dan majalah}

Setiap media komunikasi mempunyai kekuatan (power) untuk mengubah perilaku seseorang, juga mempunyai efek yang luar biasa dalam mempengaruhi pengetahuan, sikap dan tindakan individu. Sebagai contoh majalah dan surat kabar. Setiap media cetak dan elektronik mempunyai peran sangat besar dalam memberikan pengalaman dan pengetahuan dari waktu ke waktu.

Surat kabar sebagai sumber informasi mutakhir seperti yang dikemukakan oleh Mancher (1994) dalam Grossberg sebagai berikut :

- Impact : mempunyai dampak yang signifikan , penting, konsekwen terhadap kehidupan masyarakat.

- Timeliness : tepat waktu artinya bahwa surat kabar bersifat regular dalam penerbitannya, apakah harian, mingguan atau dua mingguan.

- Prominence : berulang-ulang atau kontinyu dalam penerbitannya.

- Procimity; kedekatan dengan pembacanya artinya surat kabar dapat dibaca dalam kondisi rileks dan santai.

- The Bizzare : artinya bahwa surat kabar mempunyai kesan khusus terhadap pembacanya.

- Conflict : terjadinya komplik batin antara pembaca dengan rubrik atau dengan artikel yang dibacanya.

- Currency: kemutahiran, karena surat kabar menyajikan data, informasi dan berita terkini.

Dengan menggunakan media ini maka sosialisasi program dapat tersampaikan kepada rubrik. 


\section{3) Brosur/Selebaran}

Brosur merupakan media cetak yang berisi penjelasan secara ringkas tentang sesuatu hal. Brosur menceritakan kepada masyarakat beberapa petunjuk yang meliputi gambaran umum, prosedur-prosedur dan data lainnya tentang sebuah lembaga atau perusahaan tertentu ( Djanaid : 1999: 152)

Brosur dapat digunakan sebagai bagian dari kegiatan komunikasi persuasif. Dalam suatu kegiatan, brosur dapat digunakan sebagai media pelengkap (complement) tentang informasi kegiatan yang sedang berlangsung, tetapi brosur juga dapat berdiri sendiri tanpa harus bergantung pada adanya kegiatan lain. Penyajian brosur sendiri perlu untuk diperhatikan secara sekasama, brosur harus dibuat komunikatif dalam artian dapat memikat perhatian, menarik minat, menimbulkan kesan agar brosur tersebut dapat diterima dan disukai oleh masyarakat, sehingga tujuan yang ingin disampaikan tercapai dan sesuai sasaran.

Brosur pada umummya terdiri dari selembar kertas yang dilipat menjadi tiga bagian, dalam keadaan terlipat ini memudahkan orang untuk menyimpannya. Pada pameran-pameran umumnya dijumpai brosur yang berukuran seperti tersebut di atas. Dengan ukuran yang kecil memudahkan orang untuk memasukannya kedalam tas bahkan dapat dimasukkan kedalam saku. Tetapi ukuran brosur bukanlah suatu masalah, yang terpenting informasi yang tercantum didalamnya tersampaikan kepada sasarannya.

Isi pesan perlu diperhatikan agar komunikasi berjalan dengan baik. Oleh karena itu tahapan-tahapan dalam penyusunan pesan haruslah diikuti, seperti sistem penyusunan pesan notivated sequence Alan HMonroe dalam Rahkmat dibawah ini:

Introduction Attention

Body. Need Satisfaction

Conclution. ..Visualizaton Action

Sistem penyusunan pesan Notivated Squence (Sumber: Rahkmat 1996: 296)

Pemahaman dari model ini adalah bahwa terdapat lima langkah dalam penyusunan pesan demi pencapaian komunikasi yang diharapkan atau dengan kata lain demi terciptanaya tujuan komunikasi yang dilakukan lima tahap itu : attention, need, satisfaction, visualization, action.Dalam proses komunikasi, pesan yang akan disampaikan kepada komunikan menyangkut tehnik transmisinya agar mengena sasaran dan mencapai tujuan yang diinginkan.

Brosur juga merupakan Media publisitas kelembagaan yang bersifat one-way communication, artinya setiap event, peristiwa, kejadian, disebar luaskan kepada masyarakat tanpa adanya feed-back( umpan balik) namun sifat dari terbitan ini lebih personal, menarik perhatian untuk dibaca. Dalam memuat informasi, brosur pada 
umumnya memuat hal-hal penting yang perlu diketahui oleh khalayak sasaran. Selain memuat hal-hal penting, brosur juga biasanya disertai gambar/ilustrasi yang berhubungan dengan keterangan dalam brosur. Sebagai media komunikasi brosur mengkategorikan isinya berdasarkan tiga aspek yaitu aspek informasi, aspek edukatif dan aspek persuasif. Bobot masing-masing aspek tergantung dari kebutuhan dan tujuan penyebaran brosur. Menurut Noite \& Wilcox, isi brosur membahas:
a) Pemberitahuan/ pengumuman
b) Informasi
c) Kata pengantar
d) Pendahuluan
e) Permohonan untuk melakukan kegiatan
f) Laporan berkala

(Noite \& Wilcox, 1984: 327)

\section{4). Billboard Sebagai Media Penyampai Pesan}

Billboard adalah salah satu media luar ruang yang dewasa ini telah menjadi bagian dari kehidupan masyarakat urban, yang memiliki tujuan menyampaikan pesan promosi suatu produk atau jasa. Lokasi strategis merupakan kunci keberhasilan pemasangan bilboard, agar dapat memberikan rangsangan stimulasi visual secara langsung kepada khalayak publik melalui pengaturan visual, seperti tampilan warna, gambar, tipografi / huruf, serta layout. Elemen-elemen ini diatur sedemikian rupa menjadi sebuah satu kesatuan dan ditampilkan pada media billboard agar tampak menarik perhatian dan pesan-pesannya dapat tersampaikan secara tepat kepada khalayak umum.

Billboard adalah jenis reklame media luar ruang (outdoor) dengan ukuran yang besar yang terpasang di jalan-jalan raya. Target pembaca jenis ini adalah para pengunjung yang hadir di salah satu acara yang diselenggarakan oleh Lembaga atau organisasi. .

Variasi ukuran billboard:

1) $20 \times 10$ meter horizontal

2) $18 \times 6$ meter horizontal

3) $12 \times 6$ meter horizontal

4) $10 \times 5$ meter horizontal

5) $4 \times 8$ meter horizontal / vertical, dan lain-lain

Secara umum, karakteristik media billboard dapat dirinci sebagai berikut:

a. Ukuran dan dominasi. Karena ukuran yang pada umumnya cukup besar, maka billboard mendominasi pemandangan dan mudah menarik perhatian.

b. Warna. Kebanyakan poster dihiasi dengan aneka warna, dengan gambar-gambar dan pemandangan yang realistis sehingga memudahkan pemirsa untuk mengingat pesan yang terdapat dalam billboard tersebut.

c. Pesan-pesan singkat. Karena dimaksudkan untuk menarik perhatian orang-orang yang 


\section{Vol. 2 No.1 Agustus 2017}

sedang bergerak, dan billboard mungkin saja hanya dilihat dari kejauhan, maka kalimat atau pesan-pesan tertulis, biasanya terbatas pada slogan singkat atau sekedar satu nama yang sengaja dicetak dengan huruf-huruf besar dan mencolok.

d. Zooning. Kampanye iklan secara umum dapat diorganisir dalam suatu daerah atau kota tertentu. Tetapi sebuah kampanye yang berskala nasional dapat dirancang secara lebih rinci jika pengiklannya menggunakan billboard. Pemasangan billboard dalam jumlah minimum bisa diatur di setiap kota untuk menjamin kesempatan penyimakan yang maksimum dari pemirsa. Penempatan poster secara strategis dapat menciptakan suatu kampanye iklan yang sangat ekonomis.

e. Efek mencolok. Karakteristik billboard yang paling penting adalah kemampuannya dalam menciptakan kesan atau ingatan pemirsa melalui penebalan, warna, ukuran, dan pengulangan.

\subsection{Budaya Membaca Masih di Awang-}

\section{awang}

Rendahnya budaya membaca bagi masyarakat Indonesia dan kendala-kendala yang dialami dalam meningkatkan hal itu. "Lagu lama", menanggapi alasan tentang merosotnya produksi buku dan terbatasnya jumlah perpustakaan sebagai alasan utama menanggapi tak tersedianya buku yang baik dan menarik sebagai faktor signifikan dalam menggaet calon pembaca buku. Memang selain masih kentalnya budaya lisan bagi masyarakat kita, faktor keterbatasan buku bacaan yang baik dan menarik serta keterbatasan penyebarannya juga menjadi titik pemicu rendahnya minat baca bangsa Indonesia.

Selain itu slogan untuk menumbuhkan minat baca buku yang dibuat pemerintah seperti: Budayakan membaca buku, Buku adalah jendela dunia, Biasakan memberi hadiah buku, dll. Hampir tak terdengar gaungnya di lapisan masyarakat bawah, yakni pedesaan,

kecuali anak-anak sekolah yang kebetulan mendapat pinjaman buku-buku paket pelajaran dari sekolah. Tentu, dengan slogan saja tak cukup. Ironis memang, di satu sisi pemerintah menganjurkan dan mendorong masyarakat untuk membiasakan baca buku dan membentuk budaya baca di sisi lain, upaya untuk itu tidak tertangani secara serius dan bahan bacaan itu tidak tersedia. Untuk membuktikan hal itu tak sulit, cukup kita amati berapa banyak perpustakaan di tingkat desa? Perpustakaan di tingkat desa masih minim , bahkan di kecamatan pun juga tidak semua kecamatan yang ada di wilayah Provinsi Jawa Barat tersedia perpustakaan umum. Paling, mungkin baru ada di kota atau kabupaten . Apabila kita ingin memajukan masyarakat lewat membaca maka basisnya adalah desa, terutama di era otonomi daerah ini. Dalam hal 
ini kita berbicara di pulau Jawa apalagi di luar itu, kondisinyatentu lebih memprihatinkan. Upaya meningkatkan minat baca dan pemenuhan bahan bacaan sudah seharusnya menjadi agenda utama dalam usaha mencerdaskan kehidupan bangsa selain usahausaha yang telah dilakukan pemerintah lewat dunia pendidikan. Tanpa campur tangan yang serius dari pemerintah, maka peningkatan minat baca dan pemenuhan bahan bacaan akan berjalan tertatih-tatih. Itu berarti kita tetap akan menduduki rangking kedua terbawah di antara negara-negara di Asia dalam hal pendidikan, karena masyarakat yang terpelajar (educated society) selalu berlandaskan atas kecintaan mereka terhadap buku dan membaca telah menjadi kebutuhan penting selain kebutuhan pokok sehari-hari.

Sejalan dengan permasalahan tersebut maka Perpustakaan Nasional serentak membuat program GPMB ( Gerakan Pemasyarakatan Minat Baca) yang harus diikuti oleh Perpustakaan tingkat Provinsi. Gerakan Nasional Gemar Membaca harus mampu menjangkau seluruh strata penduduk mulia usia dini, usia sekolah hingga usia dewasa.

\subsection{Gerakan Pemasyarakatan Minat Baca ( GPMB )}

Perpustakaan memiliki peran yang strategis dalam mengembangkan gemar dan budaya baca di kalangan masyarakat luas. Saat ini kehadiran perpustakaan terus mengalami perkembangan baik yang ada di lingkungan formal (golongan pendidikan, institusi), di lingkungan non formal ( yaitu golongan masyarakat) maupun di lingkungan informal (yaitu lingkungan keluarga). Namun kehadiran perpustakaanini tentunya diharapkan sejalan pula dengan pemanfaatan dan pemberdayaan yang semakin meningkat oleh masyarakat pengguna (pemustaka).

Peningkatan minat dan gemar membaca masyarakat diperlukan berbagai upaya dan pendekatan yang menarik bagi Badan Perpustakaan dan Kearsipan Daerah (BAPUSIPDA) Provinsi Jawa Barat, salah satunya menyelenggarakan " Program Pengembangan Budaya baca dan pembinaan Perpustakaan”. Kegitan pembinaan Budaya Baca Masyarakat dan Pemberdayaan perpustakaan di Jawa Barat. Melalui Road Show gemar membaca pada tahun 2011 ini. Dilaksanakan di 6 Kabupaten/ Kota di Jawa barat yaitu di kabupaten Bandung, Kabupaten Ciamis, kabupaten Kuningan, Kabupaten Bogor, Kabupaten Cianjur dan Kabupaten Karawang.

Agar pelaksanaan Road Show berjalan efektif dengan hasil yang optimal, maka dilaksanakan di kabupaten/ kota yang telah ditentukan dan pada prosesnya melibatkan perpustakaan umum kabupaten / kota sampai dengan perpustakan desa/ kelurahan, para pelajar, tim penggerak PKK kabupaten/ kota, para tokoh budaya dan tokoh masyarakat, 
mahsiswa dan organisasi masyarakat yang bergerak dalam bidang perpustakaan dan budaya baca masyarakat juga komponen terkait lainnya serta melibatkan stake holder baik publik maupun privat.

Selanjutnya materi Road Show yang disajikan bervariatif melalui penggalian atau mengangkat potensi lokal yang ada di kabupaten/ kota yang dijadikan lokasi penyelenggaraan. Gerakan Budaya Baca masyarakat pada tataran teknisnya dilaksanakan secara terintegrasi dengan melibatkan berbagai komponen di atas.

Selanjutnya mewujudkan gemar membaca masyarakat agar efektif diperlukan suatu pendekatan yaitu melalui pendekatan kultural, dengan melibatkan pemegang kebijakan daerah serta pendekatan struktural yaitu disesuaikan dengan karakteristik dan potensial lokal, dengan harapan kegiatan ini dijadikan input dalam mengambil kebijakan untuk mengembangkan program pemberdayaan perpustakaan dan budaya baca di daerah masing-masing.

\subsubsection{Dasar Hukum GPMB}

1) Undang-Undang nomor 20 tahun 2003 tentang Sistem Pendidikan Nasional.

2) Undang- Undang nomor 32 tahun 2004 tentang Pemerintahan Daerah.

3) Undang-Undang nomor 33 tahun 2004 tentang perimbangan keuangan antara Pemerintah Pusat dan Pemerintah Daerah.
4) Undang-undang nomor 43 tahun 1007 tentang Perpustakaan.

5) Keputusan Menteri Negara Pendayagunaan Aparatur Negara no 33 tahun 1998 tentang Jabatan Fungsional Pustakawan dan Angka Kreditnya.

6) Peraturan Daerah Provinsi Jawa Barat nomor 22 tahun 2008 tentang organisasi dan tatakerja inspektorat, Badan Perencanaan Pembangunan Daerah , lembaga teknis Daerah dan satuan Polisi Pamong Praja Provinsi jawa Barat.

7) Peraturan Gubernur Jawa barat nomor 67 tahun 2009 tentang Tugas pokok dan fungsi serta rincian tugas unit kerja Badan Perpustakaan dan Kearsipan daerah provinsi jawa Barat.

8) DPA nomor 1.2601770552 anggaran APBD tahun 2011 pada satuan kerja badan perpustakaan dan Kearsipan daerah Provinsi Jawa barat.

\subsubsection{Materi Road Show}

1) Workshop Budaya Baca dan Penulisan Karya ilmiah

2) Talk Show bersama pakar dan praktisi bidang budaya baca dan perpustakaan.

3) Pameran buku Perpustakaan Keliling dan Mobil sadar Arsip.

4) Sosialisasi PD-GPMB Provinsi Jawa Barat periode 2010-2014

5) Work Shop Kreasi Inovasi Berbasis Bahan Pustaka

6) Rekresai Edukasi 
7) Penampilan Aksi baca

8) Penampilan lagu- lagu Budaya Baca.

\subsubsection{Tujuan GPMB}

1) Menghasilkan karya inovatif dan kreativitas dengan membaca.

2) Meningkatkan minat baca masyarakat untuk berkunjung ke perpustakaan.

3) Meningkatkan Apresiasi masyarakat terhadap peran dan fungsimelalui pemberdayaan perpustakaan menuju masyarakat pembelajaran.

\subsubsection{Sasaran Program GPMB}

Terciptanya hasil karya inovatif dan kreativitas dengan kegiatan gemar membaca dan terselenggaranya pemberdayaan masyarakat dalam menumbuh kembangkan minat dan gemar membaca masyarakat ( reading intersest), ke arah kebiasaan membaca masyarakat ( reading hebits), agar tercapai budaya baca masyarakat ( reading Culture), menuju masyarakat pembelajaran ( Learning society) dalam mencerdaskan kehidupan bangsa.

\section{HASIL PENELITIAN}

\subsection{Daya tarik penyajian media}

\section{komunikasi cetak dalam bentuk buku panduan, brosur, surat kabar, dan billboard dalam menumbuhkan budaya baca.}

Berdasarkan distribusi jawaban para nara sumber persepsi terhadap daya tarik penyajian media komunikasi cetak dalam bentuk buku panduan, brosur, surat kabar dan billboard serta isi informasinyainformasi sudah sangat baik, hal ini mengindikasikan responden menilai akan daya tarik media komunikasi sudah cukup bagus dalam keanekaragaman informasinya, illustrasi, kelengkapan informasi, rubrik yang menarik dan keaktualitasannya dapat dipercaya melalui proses perhatian, pengertian dan penerimaan.

Seperti yang dikatakan oleh Kepala Perpustakaan Kabupaten Ciamis dan Kepala Perpustakaan Kabupaten Bogor dan kepala perpustakaan kabupaten Karawang, mengenai daya tarik penyajian brosur, buku panduan, surat kabar, bill board sudah termasuk kategori baik. Hasil wawancara dengan kepala perpustakaan dan pengelola perpustakaan mengatakan dari daya tarik penyajian semua media yang digunakan mengenai ukurannya sudah cukup. Dari jenis huruf sudah cukup tepat. Huruf pada buku panduan,brosur dan billboard jelas untuk dibaca", mereka katakan mudah untuk membaca dan mengikuti alur informasi yang disajikan karena tepat memilih huruf dan penyusunannya. Dari segi warna sudah cukup sesuai. Dari segi layout sudah cukup tepat. Sedang dari segi gambar/ilustrasi sudah cukup menarik. Kemudian design keseluruhan media penyampai informasi tersebut sudah cukup baik. Juga dari segi daya tarik penyajian sudah cukup baik. 
Mereka dimintai pendapat tentang daya tarik keseluruhan media komunikasi yang digunakan oleh GPMB, mereka berpendapat bahwa buku mempunyai daya tarik dan isi serta tampilan yang lebih menyenangkan dibandingkan dengan media lainnya . Buku memuat informasi banyak lengkap dan tuntas serta dapat dibawa kemana - mana tanpa takut rusak atau robek dan lebih menyenangkan . Buku pedoman tentang pengembangan budaya baca yang dibuat atau disusun oleh GPMB pada prinsipnya sesuai dengan harapan dan keinginan dari para pembacanya, namun jumlahnya sangat terbatas sehingga tidak semua para penyuluh atau pembimbing budaya baca tidak dapat menerima semuanya , sehingga informasi yang disampaikan kepada masyarakat hanya dapat dilakukan oleh kalangan tertentu dengan frekuensi penyampaian pesan atau informasinya tidak dapat dilakukan lebih luas dan serempak namun keunggulan dari buku dibandingkan media yang lainnya informasinya lengkap dan tuntas .

Sebetulnya brosur lebih menarik dibandingkan dengan buku karena isi informasinya singkat, padat dan sesuai dengan kebutuhan hal layak . brosur dapat dicetak banyak dan di atur sedemikian rupa dan tampilannya menarik, harganya pun lebih murah dibandingakan buku dapat dicetak sebanyak mungkin dan bisa tersebar dalam waktu yang sama kepada sasaran (hal layak masyarakat) . namun yang menjadi kendalanya adalah setelah brosur dibaca di buang begitu saja tidak seperti penghargaannya terhadap buku , buku disimpan, disusun, dan dipinjamkan kepada yang lain, sementara brosur di buang begitu saja menjadi isi keranjang sampah.

Sedangkan BillBoard dapat dibuat sedemikian menarik dan dapat menimbulkan perhatian orang yang melihatnya , isi informasinya singkat, padat dan dapat dimengerti oleh si pembacanya . akan tetapi pembacanya sangat terbatas yaitu orang yang kebetulan melihat billboard tersebut, di samping itu juga kalau membuatnya banyak tentu akan menyita waktu dan biaya juga . jadi billboard dapat dijadikan alat bantu untuk memperjelas atau melengkapi informasi dari buku - buku dan brosur .

"Penggunaan ilustrasi/foto/gambar menarik perhatian saya untuk membaca brosur, surat kabar, buku panduan dan billboard".

Dari hasil pengolahan data menunjukkan respon masyarakat diklasifikasikan sangat baik , hal yang menarik karena sampai tingkat kabupaten bahkan desa GPMB membuat acara road show dan meliputnya mendapat tanggapan yang sangat baik dikarenakan banyak illustrasi lingkungan dipublikasikan di dalam buku panduan dan brosur juga surat kabar. Hal ini sejalan dengan pernyataan Ashadi Siregar dan Rondang Pasaribu yang 
mengatakan bahwa gambar dan foto bertujuan untuk memperjelas teks/kalimat. Gambar merupakan objek penerangan yang fungsinya untuk mempertegas. Ketegasan dan kejelasannya membuat gambar atau foto lebih cepat untuk memikat mata pembaca. Gambar atau foto bisa ditempatkan pada halaman tertentu sabagai unsur yang berdiri sendiri, atau sebagai materi pelengkap untuk meperjelas suatu tulisan. Ilustrasi dimaksudkan untuk menampilkan sesuatu yang menarik perhatian (Siregar, 2000:127).

Maka dapat dilihat bahwa ada keterkaitan antara daya tarik penyajian media-media tersebut dengan menumbuhkan budaya baca terhadap masyarakat, karena hampir semua pengunjung dalam acara road show yang diadakan oleh GPMB Bapusipda Jawa Barat merasa termotivasi untuk lebih giat lagi datang ke perpustakaan untuk meningkatkan dan menumbuhkan budaya baca. Karena daya tarik penyajian brosur yang cukup baik, sehingga Pengunjung tertarik untuk membaca brosur, membaca buku panduan, membaca billboard yang di pasang di tempat acara road show itu diadakan. Pada akhirnya pengunjung mengetahui jenis jasa layanan yang diberikan oleh setiap perpustakaan untuk menumbuhkan minat baca yang disediakan untuk kemudian dimanfaatkan sesuai kebutuhan masing- masing individu.

\subsection{Isi informasi media komunikasi cetak dalam bentuk buku panduan, brosur, surat kabar, dan billbord}

\subsubsection{Kelengkapan Isi Informasi}

Para nara sumber dalam penelitian ini berpendapat media komunikasi cetak dalam bentuk buku panduan, brosur, dan billboard memberikan kelengkapan informasi di dalam isi bacaannya untuk menumbuhkan budaya baca bagi masyarakat". dalam menyebarkan pengetahuan budaya baca lengkap sesuai kebutuhan masyarakat.

Dari isi informasi yang disampaikan melalui buku panduan, brosur, surat kabar ,dan billbord memang sudah lengkap karena informasi yang di kemas pada media -media tersebut sudah mencakup semua hal yang ingin disampaikan. Brosur, buku panduan, billboard dan surat kabar bersifat memberitahukan atau menjelaskan sesuatu pada saat acara road show dalam budaya baca, maka dengan ukurannya yang relatif berbeda dari setiap media tersebut serta berbagai hal penunjang lainnya, kelengkapan informasi yang ingin disampaikan hendaknya jangan dilupakan, bahkan harus diutamakan. Informasi yang tercantum harus mancakup tujuan yang hendak dicapai dari penyebaran pesan tentang memasyarakatkan budaya baca pada pengunjung road show tingkat kabupaten .Semakin banyak dan lengkap informasi yang ada pada media-media tersebut, juga di dukung dengan pengelolaan 


\section{Vol. 2 No.1 Agustus 2017}

yang baik, maka media tersebut dapat memberikan peranan yang lebih untuk menumbuhkan budaya baca .

\subsubsection{Kejelasan, Kemudahan dan}

\section{Kesesuaian Isi Informasi}

Kejelasan isi Informasi melalui media brosur, buku panduan, surat kabar, dan billboard sudah jelas karena isinya mudah dipahami. Selain lengkap, informasi yang ingin disampaikan juga harus jelas, tepat sasaran, dan tidak berbelit-belit. Pembuatan media-media yang tepat dan jelas mencegah pembacanya untuk melakukan kesalahan dalam menafsirkan informasi yang ingin disampaikan.

Isi dari informasi yang dikemas dalam media-media tersebut mudah dipahami karena sebagian informsi yang ada pada brosur, buku panduan, surat kabar dan billboard cukup dapat dipahami. Dari kelengkapan dan kejelasan informasi suatu media diharapkan para pengunjung road show akan mudah memahami isi maupun maksud yang ingin disampaikan media tersebut, sehingga tujuan utama untuk menumbuhkan minat baca dapat tercapai.

Menurut kepala perpustakaan kabupaten Ciamis dan kabupaten Bogor isi informasi yang ada pada media brosur, buku panduan dan billboard sudah sesuai. Selain penyajian media tersebut, isi informasi dalam media perlu diperhatikan secara seksama bahkan merupakan hal utama yang harus diperhatikan, media harus dibuat lengkap, jelas, dan mudah dipahami sehingga tujuan yang ingin disampaikan oleh team road show sudah tercapai dan sesuai sasaran.

Seperti kita ketahui pengunjung road show dari berbagai kalangan, ada siswa sekolah, mahasiswa aparat kelurahan, kecamatan ,para pengelola perpustakaan juga ibu-ibu PKK yang mempunyai keinginan untuk mendapatkan pengarahan, yang urusannya dengan budaya baca. Sehingga wajar apabila Bapusipda membuat brosur dan media lainnya dengan isi informasi yang lengkap dan jelas juga mudah difahami.

"Beragamnya informasi yang diberikan dalam media komunikasi pada saat diadakan Road show", dapat mengindikasikan bahwa variasi isi/materi dari brosur dan media lainnya, dinilai selalu berbeda dan tampak menarik pembacanya. Dikarenakan isi/materi yang ada di dalam media komunikasi tersebut disajikan dalam bentuk yang bervariasi dan tidak monoton. Efek gambar dan foto yang berwarna membuat tampilan dari billboard dan spanduk juga buku panduan menjadi lebih menarik dan informasi yang ada di dalamnya dapat diterima dengan lebih baik oleh pengguna informasi sekaligus pembelajaran tentang budaya baca. Contohnya adanya slogan-slogan dalam menggunakan bahasa sunda," barudak Jawa Barat barudak sunda sabisa-bisa ...kudu bisa......pasti bias...." adalah rubrik yang memuat tentang informasi 


\section{Vol. 2 No.1 Agustus 2017}

yang ada kaitannya dengan trend terbaru, khususnya yang ada kaitannya dengan dunia pendidikan atau anak muda harus hobbi baca. Tulisan dirubrik ini juga disesuaikan apa saja yang dilakukan oleh orang kebanyakan.

Hal ini menunjukan bahwa informasi yang disampaikan banyak mengandung unsur pendidikan, hiburan dan kebudayaan tepat sasaran karena itu pokok penting media komunikasi. Hamalik (1991) mengemukakan, agar suatu informasi/pesan yang disampaikan sampai pada pengguna serta dapat memberikan kegunaan/manfaat bagi penerima, maka harus memiliki kejelasan informasi/pesan baik dari segi kandungan isi, materi informasi maupun dengan penguasaan bahasa pemakainya. Jadi informasi dapat terpenuhi jika informasi tersebut jelas dan dapat memberikan manfaat bagi pembacanya sesuai dengan kebutuhan, baik dari daya tarik tampilan visual maupun dari isi informasinya.

\subsection{Kendala yang ditemukan dalam}

\section{penyebaran informasi melalui media}

\section{komunikasi dalam bentuk buku} panduan, surat kabar, billboard untuk menumbuhkan budaya baca.

Menurut Kepala perpustakaan kabupaten Ciamis dan Kabupaten Bogor, juga kabupaten Karawang beserta pengelolanya para pengelolanya, mereka senada berpendapat: kendala yang ditemukan mengenai efektivitas brosur, buku panduan, bill board, dan surat kabar sebagai media penyampai informasi dalam acara road show dilihat dari segi penyebarannya ternyata tidak ada kendala, namun belum semua menterapkan isi pesan yang ada pada media tersebut, dan penyebarannya kurang meluas, sebaiknya jangan hanya pada acara road show saja himbauan dan pesan yang dikemas pada media tersebut dibagikan pada pengunjung. Hendaknya Bapusipda secara rutin membimbing dan memberikan brosur dan jenis media lainnya secara rutin pada perpustakaan tingkat kabupaten/ kota yang ada di Jawa Barat.

Kendala dari buku adalah harganya mahal tentunya tidak terjangkau oleh masyarakat , namun karena buku pedoman diperoleh secara Cuma - Cuma maka kendala tersebut bisa ditangani, asal dari pihak pengurus GPMB dapat membiayainya.

Seperti apa yang dikatakan oleh pihak pengelola Perpustakaan Kabupaten Ciamis dan Kabupaten Bogor juga Karawang, pada saat peneliti mewawancara mengatakan: bahwa Perpustakaan ini sudah menjadi binaan Bapusipda dan bekerjasama dengan Dinas Pendidikan Jabar, sehingga dengan mudah dapat menyebarkan brosur, atau media lainnya.

Kendala lainnya dikarenakan mayoritas pengunjung hanya mengambil brosur dan kemudian tidak sering membaca brosur tersebut Hal ini juga dikarenakan frekuansi 


\section{Vol. 2 No.1 Agustus 2017}

kunjungan GPMB dalam mengadakan road show hanya 1 tahun sekali.

Perlu diadakan suatu tindakan dintaranya promosi budaya baca pada masyarakat lebih gencar lagi dan dapat menjangkau masyarakat pengunjung perpustakaan atau biasa dikatakan pemustaka - Dalam hal ini frekuensi penyebaran dari brosur sebagai media promosinya menumbuhkan budaya baca harus lebih ditingkatkan. Kemudian juga penjelasan tentang jenis-jenis layanan yang ada pada perpustakaan perlu di informasikan, sehingga jasa layanan perpustakaan yang ada dapat dimanfaatkan secara maksimal juga program road show lebih bermanfaat lagi.

Minat baca lebih merupakan keadaan yang bervariasi sesuai dengan lokalitas di setiap elemen penyusun gerak masyarakat. Kepekaan dan variasi kebutuhan informasi di masyarakat itulah yang akan banyak menentukan keberhasilan suatu bacaan. Kurang relevan jika kita membandingkan minat baca/budaya baca antara Indonesia dan Jepang misalnya; yang sering membuat kita menunduk minder. Namun, bukan berarti kita harus tetap berbangga diri dengan rendahnya minat baca tersebut atau berdiam diri tanpa upaya meningkatkan minat baca masyarakat. Berdalih toh, tiap-tiap bangsa berbeda, mengapa harus meniru Jepang atau negara lain. Upaya kita agar tidak minder dan tidak berbangga diri dengan rendahnya minat baca tersebut,harus dimulai dengan menanamkan minat dan kemampuan membaca sedini mungkin kepada anak anak kita sebagai generasi penerus agar kita dapat sejajar dengan bangsa lain yang minat bacanya sudah tinggi.

John Durie dari Inggris dalam bukunya "The Reformed Library-keeper" menyatakan bahwa peranan pertama Pustakawan adalah sebagai pendidik, bukan sekedar penjaga koleksi yang bekerja untuk mencari nafkah. Pastakawan harus berperan sebagai "agent of the advancement of universal learning”, pelopor untuk memajukan pengetahuan semesta.

Pustakawan dapat menjadi komunitas yang sangat berpengaruh bagi pertumbuhan dan perkembangan masyarakat gemar membaca Minat dan kemampuan masyarakat gemar membaca dapat dibentuk dari perpustakaan di mana dia berada apakah di lingkungan perpustakaan sekolah, perguruan tinggi,perpustakaan umum maupun perpustakaan khusus .

Di sini peran nara sumber pada saat mengadakan road show Gerakan Budaya Masyarakat Membaca cukup besar dan sangat penting untuk mengembangkan minat baca anak-anak. Sering-seringlah tunjukkan ketertarikan Anda terhadap ketertarikannya pada buku yang dibacanya. Tanyakan siapa tokoh ceritanya, atau bagaimana akhir ceritanya. Tunjukkan buku lain yang membahas tentang hal yang sama untuk 
menambah informasi yang sudah didapatnya. Anak akan merasa mendapat angin kalau ada orang lain, atau orang tuanya ikut memberi perhatian terhadap buku yang dibacanya. Inilah kunci untuk menolong anak- anak bangsa kita agar memiliki kebiasaan membaca.Kalimat tersebut di ucapkan oleh ibu Netty ( istri Gubernur JABAR) sebagai pelindung dan pembina GPMB.

Ada banyak faktor yang menyebabkan kemampuan membaca anak-anak Indonesia tergolong rendah. Pertama, ketiadaan sarana dan prasarana, khususnya perpustakaan dengan buku-buku yang bermutu dan memadai. Bisa dibayangkan, bagaimana aktivitas membaca anak-anak kita tanpa adanya buku-buku bermutu. Untuk itulah, ketiadaan sarana dan prasarana, khususnya perpustakaan dengan buku-buku bermutu menjadi suatu keniscayaan bagi kita. Dengan kata lain, ketersediaan bahan bacaan memungkinkan tiap orang dan/atau anak-anak untuk memilih apa yang sesuai dengan minat dan kepentingannya. Dari situlah, tumbuh harapan bahwa masyarakat kita akan semakin mencintai bahan bacaan. Implikasinya, taraf kecerdasan masyarakat akan kian meningkat; dan oleh karena itu isyarat baik bagi sebuah kerja perbaikan mutu perikehidupan suatu masyarakat.

Kedua, banyaknya keluarga di Indonesia yang belum mentradisikan kegiatan membaca. Padahal, jika ingin menciptakan anak-anak yang memiliki pikiran luas dan baik akhlaknya, mau tidak mau kegiatan membaca perlu ditanamkan sejak dini. Bahkan, Fauzil Adhim dalam bukunya Membuat Anak Gila Membaca (2007) mengatakan, bahwa semestinya memperkenalkan membaca kepada anak-anak sejak usia 0-2 tahun.

Sebab, pada masa 0-2 tahun perkembangan otak anak amat pesat (80\% kapasitas otak manusia dibentuk pada periode dua tahun pertama) dan amat reseptif (gampang menyerap apa saja dengan memori yang kuat). Bila sejak usia 0-2 tahun sudah dikenalkan dengan membaca, kelak mereka akan memiliki minat baca yang tinggi. Dalam menyerap informasi baru, mereka akan lebih enjoy membaca buku ketimbang menonton TV atau mendengarkan radio. Beberapa temuan riset kualitatif tentang minat baca oleh Primanto Nugroho (2000) menunjuk pada sebuah kesimpulan bahwa duduk perkara minat baca ternyata bukan soal kalkulasi tinggi atau rendah.

Pustakawan menjadi komunitas yang sangat berpengaruh bagi pertumbuhan dan perkembangan masyarakat gemar membaca Minat dan kemampuan masyarakat gemar membaca dapat dibentuk dari perpustakaan di mana dia berada apakah di lingkungan perpustakaan sekolah, perguruan tinggi,perpustakaan umum maupun perpustakaan khusus 
Vol. 2 No.1 Agustus 2017

\section{KESIMPULAN DAN SARAN}

\subsection{Kesimpulan}

Kesimpulan ditarik berdasarkan tujuan penelitian. Ingin mengetahui daya tarik penyajian media komunikasi cetak dalam bentuk buku panduan, brosur, billboard, ingin mengetahui isi informasi media komunikasin cetak dalam bentuk buku panduan, brosur,surat, billbord, juga ingin mengetahui kendala yang ditemukan dalam penyebaran informasi melalui media komunikasi dalam bentuk buku panduan, billboard untuk menumbuhkan budaya baca . Melalui proses pengumpulan data, pengolahan data secara kualitatif, kesimpulan dari penelitian ini adalah sebagai berikut:

1) Daya tarik penyajian media komunikasi cetak dalam bentuk buku panduan, brosur dan billboard untuk menumbuhkan budaya baca bagi masyarakat sudah cukup baik. Kemudian design keseluruhan media penyampai informasi tersebut sudah cukup baik. Juga dari segi daya tarik penyajian sudah cukup baik. Terdapat keterkaitan antara penyajian brosur secara keseluruhan dalam pemenuhan daya tarik menumbuhkan budaya baca Semakin baik tampilan brosur,buku panduan dan billboard, dari segi jenis huruf, warna, tata letak, maupun gambar atau ilustrasi, maka semakin banyak pengunjung road show GPMB yang mamanfaatkan jasa perpustakaan untuk menumbuhkan budaya baca.

2) Kandungan informasi brosur, buku panduan, billboard untuk menumbuhkan daya tarik pengunjung road show GPMB dalam rangka menumbuhkan budaya baca, sudah cukup jelas. Dari isi informasi yang disampaikan melalui buku panduan, brosur, dan billbord memang sudah lengkap karena informasi yang di kemas pada media -media tersebut sudah mencakup semua hal yang ingin disampaikan. Kejelasan isi Informasi melalui media brosur, buku panduan,dan billboard sudah jelas karena isinya mudah dipahami Terdapat keterkaitan antara kandungan informasi brosur,

buku panduan dan billboard dalam menumbuhkan budaya baca pengunjung road show GPMB. Kandungan isi informasi dalam media komunikasi yang di gunakan, yang meliputi elemen kelengkapan, kejelasan, kemudahan untuk dipahami mempengaruhi tingkat budaya baca, apabila tingkat budaya baca sudah tinggi maka akan mempengaruhi juga pemanfaatan perpustakaan yang ada di setiap sekolah, desa pada setiap kota dan kabupaten yang ada di Jawa Barat, terutama Kabupaten Ciamis, Bogor dan Karawang.

3) Dapat disimpulkan kendala yang ditemukan dalam penyebaran informasi 
melalui media komunikasi, dalam bentuk buku panduan, brosur dan billboard untuk menumbuhkan budaya baca, sebagai media penyampai informasi dalam acara road show dilihat dari segi penyebarannya ternyata tidak ada kendala, namun belum semua menterapkan isi pesan yang ada pada media tersebut, dan penyebarannya kurang meluas, sebaiknya jangan hanya pada acara road show saja himbauan dan pesan yang dikemas pada media tersebut dibagikan pada pengunjung. Hendaknya Bapusipda secara rutin membimbing dan memberikan brosur dan jenis media lainnya secara rutin pada perpustakaan tingkat kabupaten/ kota yang ada di Jawa Barat.

Kendala lainnya dikarenakan mayoritas pengunjung hanya mengambil brosur dan kemudian tidak membaca brosur tersebut Hal ini juga dikarenakan frekuansi kunjungan GPMB dalam mengadakan road show hanya 1 tahun sekali. Terlihat dari masih banyaknya pengunjung road show yang hanya satu kali menerima dan membaca brosur atau buku panduan juga membaca isi pesan yang ada di billboard, karena billboard, buku panduan hanya dapat di baca pada saat diadakan roadshow saja.

\subsection{Saran}

1) Hendaknya Bapusipda secara rutin membimbing dan memberikan brosur dan jenis media lainnya secara rutin pada perpustakaan tingkat kabupaten/ kota yang ada di Jawa Barat.Perpustakaan ini sudah menjadi binaan Bapusipda dan bekerjasama dengan Dinas Pendidikan Jabar, sehingga dengan mudah dapat menyebarkan brosur, atau media lainnya setiap saat bukan pada saat diadakan roadshow saja.

2) Berdasarkan hasil penelitian yang telah dilakukan penggunaan brosur, buku panduan,dan billboard sebagai media komunikasi dirasakan sudah cukup berhasil, tetapi masih ada kekurangan karena penerapannya belum dilakukan secara maksimal. Oleh masyarakat.Peningkatan frekuensi penyebaran dari brosur masih perlu ditingkatkan agar pemanfaatan perpustakaan oleh masyarakat untuk meningkatkan budaya dan minat baca lebih optimal lagi.

3) Bapusipda lebih meningkatkan atau mengintensitaskan program roadshow dalam menumbuhkan budaya dan minat baca masyarakat, melalui media yang tepat salah satunya media massa. Pemilihan media massa dikarenakan jangkauannya yang luas dan dapat langsung diterima oleh masyarakat. 


\section{DAFTAR PUSTAK A}

Aeker, David and john G.Myres. 1987. Advertising Management. New Delhi Prentice Hall.

Agustrijanto, 2001 Copywriting Seni Mengasah Kreativitas dan memahami Bahasa Iklan, Bandung ; Remaja Rosda Karya

Anggoro, M. Linggar, 2000. Teori dan Profesi Kehumasan serta aplikasinya di Indonesia. Jakarta: Bumi aksara persada

Arsyad,Azhar. 2002. Media Pembelajaran. Jakarta : Raja Grafindo

Bangun, Antonius . 1992. Kepustakawanan Indonesia : potensi dan tantangan, Jakarta : Kesaint Blanc.

Beenham, Rosemary and Collin Horrison. 1990. The Basic of Librarianship, London : Clive Bingley.

Bungin, Burhan. 2008. Penelitian Kualitatif. Jakarta: Prenada Putra Grafik

Departemen Pendidikan dan Kebudayaan RI. 1994. Perpustakaan Perguruan Tinggi : Buku Pedoman. Jakarta : Departemen Pendidikan dan Kebudayaan RI.

Ganda, Yahya. 1995. Petunjuk Praktis Cara Mahasiswa Belajar Di Perguruan Tinggi. Jakarta : Rizky Grafis.

Littlejohn, Stephen W. 1999. Theories of Humun Communication, Sixth Edition. New Mexico: Wodsworth Publishing Company

Magnis, Suseno 1997 Manajemen periklanan:Konsep dan aplikasinya di Indonesia. Jakarta : Pustaka utama grafiti.

Mulyana, Deddy. 2001. Ilmu Komunikasi Suatu Pengantar, Bandung: Remaja Rosdakarya.

Noite, W Lawrence \& Dennis Wilcox 1984. Effective Publicity, How to Reach The Public. New York: John Miley \& Son.

Jefkins, Frank. 1997 Periklanan ed 3 , Jakarta: Erlangga.

Rachmadi, F. 1992. Publik Relations dalam Teori dan Praktek, Jakarta: Gramedia Pustaka Utama.
Rakhmat, Jalaluddin. 1998. Metode Penelitian Komunikasi, Bandung: Remaja Rosdakrya.

Rejeki, Sri 2000. Pedoman Umum Penyelenggaraan Perpustakaan Umum. Jakarta: Perpustakaan Nasional RI.

Rohanda. 2009 Pemberdayaan Perpustakaan desa oleh Masyarakat Jawa Barat Fikom Unpad.

Syaukani. Gaffar, Affan. Rasyid, Ryaas, 2002. Otonomi Daerah Dalam Negara Kesatuan, Yogayakarta: Pustaka Pelajar.

Wright, Charles Robert Penyunting Djalaludin Rakhmat, Msc. 1985. Sosiologi Komunikasi Massa. Remaja Karya Bandung. 